\title{
Paper hanging numbers and the business of wallpaper in the 1860s
}

Christine McCarthy, Interior Architecture Programme, School of Architecture, Victoria University, Wellington

ABSTRACT: This paper will present research on wallpaper advertising in the nineteenth century, focussing in particular on the 1860s.

The 1860s was a significant time for the use of wallpaper in New Zealand. At this time, when the Pākehā population first exceeded that of Māori, the national's wealth resulted from the discovery of gold in Otago and the West Coast, sheep farming, and the influx of British troops to support the Colonial government's involvement in the New Zealand wars. It was a time when it appears that wallpaper retailing was truely established. Wallpaper was used to cover interior linings, usually over scrim, linen, calico or newspapered walls. Tender Notices from the 1860s indicate that wallpaper was used in houses and cottages, ${ }^{1}$ saddlers', ${ }^{2}$ shops, $^{3}$ offices, ${ }^{4}$ hotels, ${ }^{5}$ halls, ${ }^{6}$ banks, ${ }^{7}$

${ }^{1}$ for example: "Dunedin, Wednesday, Dec. 25 ... The house of Mr W.J. Henningham ... " p 4; "To Painters, Paperhangers, Glaziers, Etc. [tender J.B. Cameron]" p 1; "Thursday, December 28.: Leasehold Property.: Chapelstreet" p 2; "To Painters And Paperhangers.: Tenders will be received until Thursday the 6th inst." $\mathrm{p} 2$.

2 "To Painters.: Tenders will be received ... John Gellatly, Saddler,: Dee-street" p 3.

3 "To Painters And Paperhangers.: Ben. Smith, Architect" p 3; "Wanted, Tenders for Canvasing and Papering" p 4. theatres $^{8}$ athenaeum, ${ }^{9}$ masonic lodges, ${ }^{10}$ manses, ${ }^{11}$ lunatic aslyums, ${ }^{12}$ Supreme Courts, ${ }^{13}$

4 "Public Works ... Your Committee have accepted ... a sum of L10 5 s." p 8.

5 "Tenders Wanted for painting [tenders McGuire and Lynch]" p 3; "Tenders are invited for the Painting, Papering, \&c., to be done at the Swan Hotel." p 3; "To Painters And Paper-Hangers.: Tenders will be received, until noon." p 1; "Wanted. Tenders for Painting and Papering Dunedn Hotel." p 3; "Tenders are required [tender Smith and Co.]" p 3; "Tenders wanted, labor only, for Painting, Papering, and Glazing" p 5; "Tenders wanted for painting, glazing, calicoing, and papering." $\mathrm{p}$ 3.

6 "Tenders: Tenders are invited for Paperhanging [advert J.M. Vivian, Foresters Hall]" p 2; "Odd Fellows' Hall,: To Paperhangers, Bricklayers, and Carpenters." $\mathrm{p} 2$

7 "Tenders are required for Painting [tenders N.W. Dike, Bank of Australasia]" p 3; "Wanted Tenders for Painting and Papering the Union Bank" p 3.

8 "Paper-Hangers wanted at the New Theatre [advert P. Griffin, at S.W.Alcorn's]" p 3; "Princess Theatre" Otago

Witness $\mathrm{p} 5$.

9 "Napier Athenæum" p 2.

10 "Auckland Provincial Council: Wednesday" p 4.

11 "Tenders required for the painting and papapering[sic] of Manse" p 9; "To Painters And Paperhangers [tender A. Whiteford.]" p 3.

12 "Tenders Wanted, for Painting and Papering the new schools, $^{14}$ hospitals, ${ }^{15}$ and Provincial Government buildings. ${ }^{16}$ Wallpaper was, in this regard, a ubiquitous building material.

\begin{tabular}{|l|c|c|}
\hline & $\begin{array}{l}\text { Unique } \\
\text { advertisements }\end{array}$ & $\begin{array}{l}\text { Total } \\
\text { advertisements }\end{array}$ \\
\hline $1841-67$ & 763 & 7,340 \\
\hline $1841-67$ & 473 & 6,985 \\
\hline $\begin{array}{l}\text { percentage of ads } \\
\text { in the 1860s }\end{array}$ & $62 \%$ & $95 \%$ \\
\hline
\end{tabular}

Figure 1: Number of advertisements for wallpaper in the 1860s

The 1860s was also distinctive as being the decade when the amount of imported wallpaper, or paperhangings, as they were known, was sufficient to warrant their discrete listing in the official importing figures, beginning from 1867. Significant

building" p 1.

13 "Monday, November 7 ... The temporary provision for Supreme Court-house" p 4.

14 "Abstract Of The Receipts and Expenditure Of The Dunedin School Committee" p 3.

15 "Hospital: Tenders for Papering and Painting" p 2.

16 "Tenders Accepted" p 5. 
changes appear to have occurred in the marketing of wallpaper during the 1860s, as indicated by an analysis of 763 distinct advertisements (yeilding 7,340 repeats) from 1841-67.

Of these newspaper advertisements, 473 (or $62 \%$ ) were published in the 1860s (up to 1867) and these 473 advertisements yeilded 6,985 repeats (just over $95 \%$ of the wallpaper advertisments published since 1841). Without quantifiable data on wallpaper consumption, we can only establish that a significant increase in newspaper advertising of, as distinct from selling of, wallpaper occurred. ${ }^{17}$ In contrast, the increase of advertisements, the percentage of new merchants selling wallpaper each year declines. Over the period from 1841-67, 262 different merchants, and tradespeople sold wallpaper; 130 of these $(49.6 \%)$ were new merchants in the 1860s, and it appears that sellers stay in, rather than leave, the retailing of wallpaper, suggesting that, wallpaper was becoming an increasingly viable commodity.

17 Walsh has observed that newspaper advertising was often part of a larger strategy of store and product promotion. Walsh, "The Advertising and Marketing of Consumer Goods in Eighteenth-Century London" pp 7995.
This contrasts with the percentages for the 1840 s and the 1850 s as follows:

\begin{tabular}{|l|c|c|c|}
\hline & Total & New merchants & $\begin{array}{c}\% \text { new } \\
\text { merchants }\end{array}$ \\
\hline $1841-49$ & 38 & $38(100 \%)$ & $14.50 \%$ \\
\hline $1850-59$ & 131 & $94(71.8 \%)$ & $35.90 \%$ \\
\hline $1860-67$ & 181 & $130(71.8 \%)$ & $49.60 \%$ \\
\hline $1841-67$ & 262 & 262 & $100 \%$ \\
\hline
\end{tabular}

Figure 2: Numbers of Wallpaper sellers

The nature of who sold wallpapers also changed. Up to the 1860 s a great diversity of sellers emerged and included an architect ( $\mathrm{F}$ Armson), ${ }^{18}$ auctioneers, drapers, furniture merchants, ironmongers, stationers, upholsters, paint shops, commission agents, real estate agents, and an undertaker. ${ }^{19}$

What changes from the 1860s is a narrowing of the types of sellers and an indication of a possible shift from the dominance of General Merchants (including auctioneers) to more specialist Decorating Suppliers. The comparative number of general merchants and auctioneers selling wallpaper gradually decreases, as Decorators, Tradespeople, and

18 "Furnishing Ironmongery, \&c. [advert F Armson]" p 1.

19 "Notice Of Removal.: David Taylor [advert]" p 4.
Building Suppliers begin to stock and sell wallpapers directly to the public. Auctions, which were the dominant mode of selling in 1841, give way to other modes of retail selling.

\begin{tabular}{|c|c|l|l|l|c|}
\hline & Total & $\begin{array}{l}\text { General } \\
\text { Merchants } \\
\text { includes } \\
\text { auctioneers) }\end{array}$ & $\begin{array}{l}\text { Decorators/ } \\
\text { Trades people }\end{array}$ & $\begin{array}{l}\text { Building } \\
\text { Suppliers }\end{array}$ & Other \\
\hline $\begin{array}{l}1840- \\
1849\end{array}$ & 38 & $32(84.2 \%)$ & $5(13.2 \%)$ & $0(0 \%)$ & $\begin{array}{c}1 \\
(2.6 \%)\end{array}$ \\
\hline $\begin{array}{l}1850- \\
1859\end{array}$ & 131 & $124(94.7 \%)$ & $5^{*}(3.8 \%)$ & $0(0 \%)$ & $\begin{array}{c}2 \\
(1.5 \%)\end{array}$ \\
\hline $\begin{array}{l}1860- \\
1867\end{array}$ & 181 & $129(71.3 \%)$ & $39(21.5 \%)$ & $9(5 \%)$ & $\begin{array}{c}4 \\
(2.2 \%)\end{array}$ \\
\hline
\end{tabular}

Figure 3: Types of Wallpaper sellers (* all 5 were new sellers)

The inclusion of paperhangings as a discrete item in importing figures in 1867 no doubt reflects the significant increase in wallpaper imports into New Zealand. If the assumption of a correlation between newspaper advertisements and wallpaper importing is correct, the grow in imports might look similar to the following graphs. 


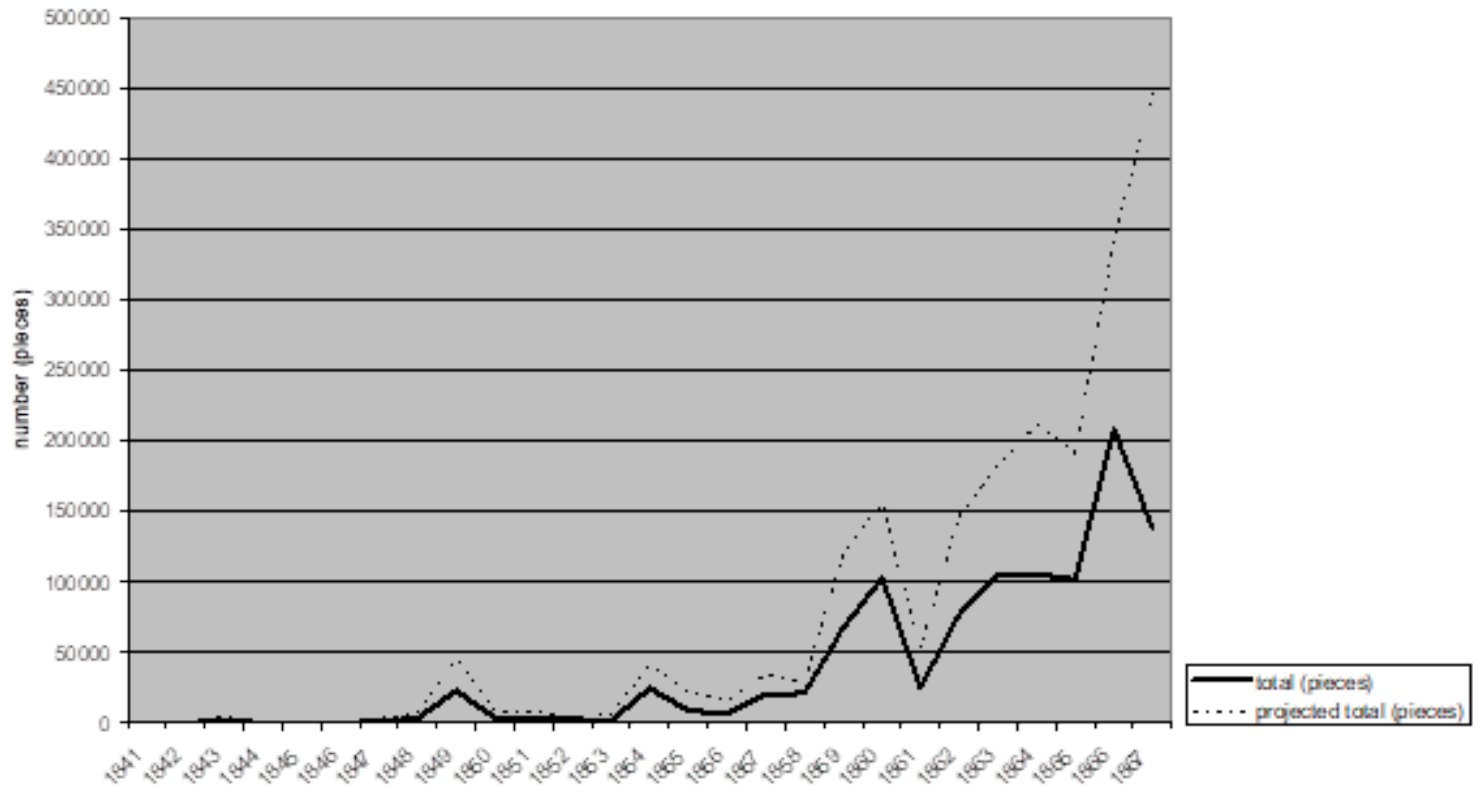

Figure 4: Total known and projected total (wallpaper 1841-66). The projected total amount is calculated by multiplying the average amount by the number of unique advertisements that year.

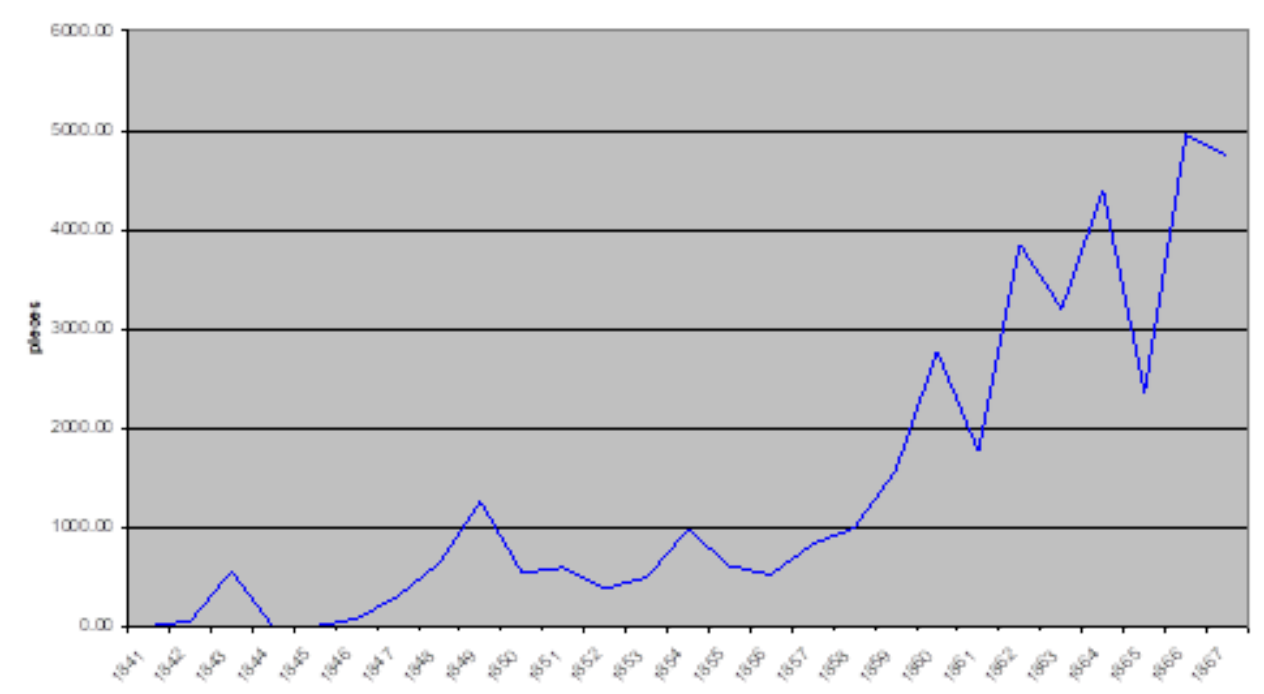

Figure 5: Average Amount (wallpaper advertised, pieces)
The amount of wallpaper advertised (the average amount advertised, the total listed in advertisements, and the total projected) increases significantly. ${ }^{20}$ The average amount of wallpaper advertised increased from 50 pieces $^{21}$ in 1842 to 1,566 pieces in 1859 . The total in 1842 was 50 pieces, the total in 1860 was 102,691 . The projected total in 1842 was 100 pieces, by 1859 the amount was 120, 576 pieces, and, except for a dip in 1862, the number of wallpaper advertisements continued to rise - suggesting the dizzy heights of 446,805 pieces was reached in 1867 . These numbers, as mentioned previously, are derived from an analysis of wallpaper advertisements. In 1867 the Statistics of New Zealand first began to record wallpaper importing. These records give the total wallpaper in the evasive unit of packages. 923 packages of paperhangings, worth a total of $£ 13,560$, were imported into NZ in 1867 $\mathrm{NZ} \$ 1,397,510.20$ in 2010, and a monetary value in 1867 comparable to the $£ 12,406 \mathrm{New}$ Zealand spent on salt that year, which, given the low access to refrigeration and the

${ }^{20}$ The projected total amount is calculated by multiplying the average amount by the number of unique advertisements that year.

${ }^{21}$ A piece is 12 yards by 20 inches. 


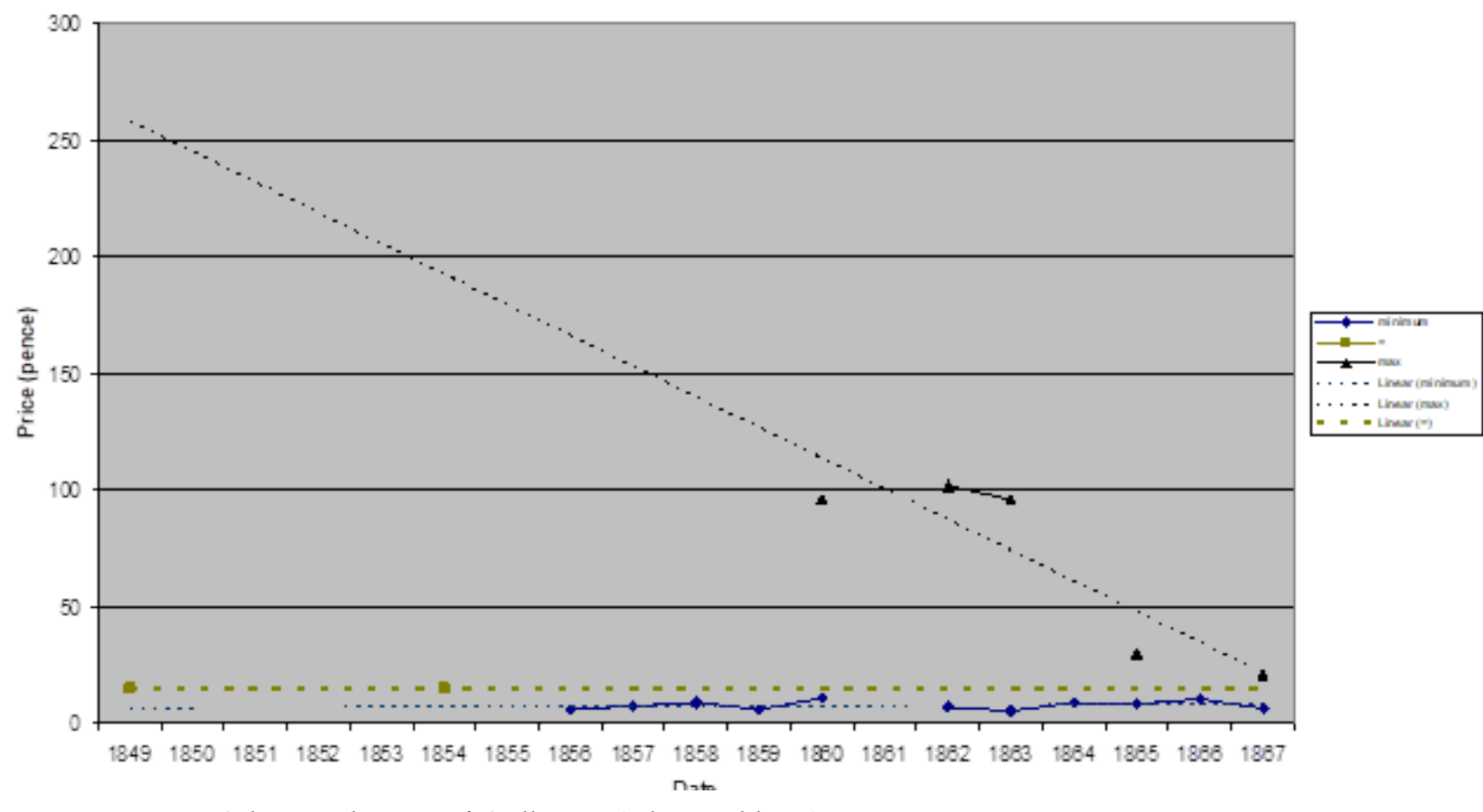

Figure 6: Advertised Prices of Wallpaper (n.b. trend lines).

significance of salt as a food perservative, appears to be significant.

As the amount of wallpaper advertisements increased, the maximum price stated fell dramatically. Much of this can be attributed to changing manufacturing methods - the introduction in the mid-nineteenth century of mechanical manufacture - as well, no doubt, due to wallpaper's increased availability in New Zealand. The lowest prices appear stable at about $6 p$, but in fact in real terms rose slightly, as general CPI was approx $-2.1 \%$ at the time. ${ }^{22}$

Changes also occurred in the language used to sell wallpapers. Language which stressed the variety of wallpapers was the prime persuasive technique that sellers used to persuade the public, promoting: choice (in pattern and price), the potential for greater

22 "Inflation Calculator" n.p. individualism - and possibly the ability to reflect class status. ${ }^{23}$

In the advertisements which commit the finances to extra lines of advertising, fashion and exclusivity are themes that are apparent. Exclusively and supremacy are often indicated via geographic references. Reference to boat names, for example, commonly indicated currency and centre of manufacture. More than this though are the unsubstantiated claims of unequalled status. Stallard and Mills, Plumbers, Painters and Ornamental Paperhangers, claimed in September 1860 that the "quality, variety, and cheapness [of their paper hangings], cannot be equalled in the province."24 They were based in Nelson - a thriving city, an important international port, and one of New Zealand's key centres of wallpaper commerce. Nelson was, it seems, a hot bed for superlatives.

W Jenkin's two months later made similar but

${ }^{23}$ The analysis of qualitiative descriptions (following the methodology used by Lyna \& van Damme "A strategy of seduction?" pp 100-121) indicated that: variety,

superiority, newness, cheapness and suitability were qualities promoted by nineteenth-century New Zealand wallpaper sellers. McCarthy "Before Official Statistics" forthcoming.

24 "Paperhangings! [advert Stallard and Mills]" p 2. 


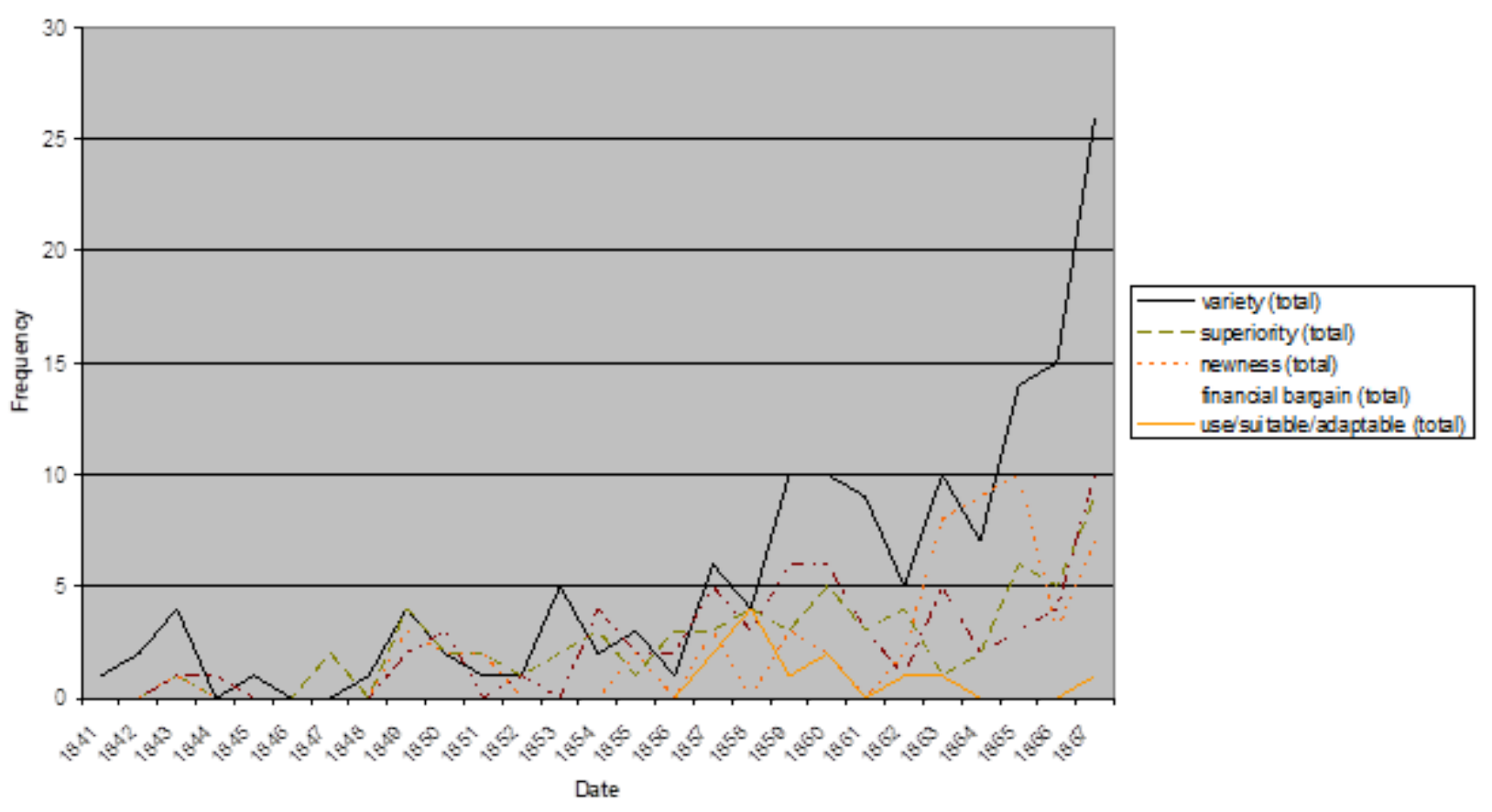

Figure 7: Persuasive Advertisements

less ambitious claims. His paperhangings were "[t]he Cheapest Lot ever offered in Nelson," and included a "superior assortment of Oak Panelling and Marble Ceiling Papers, all very cheap."25 Stallard and Mills though appear to consistently locate themselves at the premiere end of the wallpaper marketplace. The next year they have the "latest designs,"

25 "Paper Hangings. - The Cheapest Lot ... W. Jenkins's" p 4. carried by the good ship "Gladiator," which "for cheapness and beauty of pattern, cannot be equalled in the province."26 They were also the only firm to refer to stocking Exhibition papers in their advertisements, promoting the fact in March 1863 that: "A beautiful assortment of English and French Exhibition Prize Papers, in every variety, may now be

26 "Paperhangings! Paperhangings!! Paperhangings!!! [advert Stallard and Mills]" p 2. inspected at the new premises of: Stallard and advertisement suggests that the papers they were selling had been the patterns exhibited at the Great London Exposition, which closed in November 1862. Paperhangings like other products of industry were exhibited at international exhibitions, and the late nineteenth century was a time when industrial rivalry was keen between the Anglo and Franco empires. The nationalistic promotion of William Morris has been argued to be a byproduct of the English feelings of inadequacy over the matter. ${ }^{27}$ Noting the rivalry apparent in Nelson is not simply a flippant comment. Another Nelson Decorator, Thomas B. Louisson claimed, the month after Stallard and Mills advertised their Exhibition Prize Papers, that his papers were "selected by a Nelson merchant now resident in England expressly for the Nelson market."28 Delivered to New Zealand by the Electra, these papers comprised "[p]apers adapted for the drawing and dining-room, parlours, bedrooms, halls, \&c., \&c., at prices suitable to all parties." 29

${ }_{27}$ Woods "An object lesson to a philistine age" pp 159171.

28 "Superior Paper-Hangings, Per Electra.: T.B. Louisson" p 2.

29 "Superior Paper-Hangings, Per Electra.: T.B. Louisson" p 2. 
Nelson though was not the only city in New Zealand with assertive wallpaper merchants. The return of the Electra in 1866 brought, according to $\mathrm{W}$ Tustin, "one of the largest and best assorted: Lot Of Paperhangings: Ever introduced into Wellington, including every pattern and design, and at all prices."30 In 1867 though William's Oil and Color Store in Hastings Street, Napier added another level of customer guarantee. He announced, of his stock of wallpapers, that: "[h]aving been carefully bought in the Home Market by his brother, he can highly recommend them as being of the best quality." 31

This emphasis on quality, derived from intimate connections throughout the trading system, and international endorsement, supported superlative market positioning. While these advertisements do not represent the mass of wallpaper advertising, which were often a bare mention of the word "paperhangings" in a lengther list of goods and products, they do indicate the value systems of which nineteenth-century wallpaper was a part.

30 "Just Received, ex Electra [advert W. Tustin]" p 3.

31 "Just Arrived,: Ex "John Bunyan," from London ... At Williams' Oil And Color Store" p 2.
Wallpaper was both a pragmatic and a fashionable commodity. Its function as fashion item is clear in the use of adjectives such as "new" and descriptions of stock as "fashionable,"32 as well as more detailed descriptions, usually linked to assertions of quality. An example, from early 1868, from Louisson stresses variety, quality and range of decorative function:

a Splendid Assortment of Drawing-room, Dining-room Parlour, Bedroom, and Hall Paper-Hangings, Centrepieces, and Cornices; Washable Oaks, Marbles, Flocks, \&c., \&c.: The whole of these are of the newest styles, from the best English houses, and purchased so favourably that quality and price will be found to be most satisfactory to those desirous of selecting from this shipment. ${ }^{33}$

This detail of stock description was not common. There is, for example, only one reference to Scene papers in the 763 unique advertisements from 1841-67, and this instance was the result of unknown but "compelling" circumstances:

The undersigned finds himself compelled to Dispose of the greater portion of his Household Furniture, brought

32 "Friday, 12th April, 1867.: To Builders, Contractors, Ironmongers ... Mr James Smith" $\mathrm{p} 1$.

33 "T.B. Louisson, Painter, Glazier, and House Decorator" p 2. out from England, consisting in part of the following - ... 5,000 Pieces of Wall and Hall Papers,: At such prices as will ensure a speedy sale. Notice given when ready.: ... A Variety of Marble and Scene Papers, for halls and passages. ... Edwin S. Brookes. ${ }^{34}$

5,000 pieces of wall and hall papers was a substantial amount. Brett's Colonists' Guide of 1883 states that about eight pieces of English paper were needed to paper a room with a height of 12 feet $(3.7 \mathrm{~m}){ }^{35}$ suggesting that Edwin Stanley Brookes was attempting to sell enough wallpaper to paper about 600 rooms and enough for about 100 houses - though Brookes does not appear to have been a trader. There are no other advertisements in his name, but there is a later reference to an Edwin Brookes, Baptist minister, and his son, of the same name, who appears to have been a surveyor. ${ }^{36}$

Wallpaper's fashionability was not dissimilar to that we might more commonly think of in terms of haute couture. Stallard and Mills advised their customers in 1861 that: "[g]entlemen about to repaper their

34 "Junction of Queen and Grey-Streets [advert Edwin S. Brookes]" p 3.

35 Brett's Colonists' Guide p 564.

36 "Marriages" (20 February 1869) p 3; "Marriages" (15 February 1870) p 8; "'Sayings of the Ancients'"' p 3. 
resdences[sic] for the summer season will be well repaid by visiting [them]."37 Even earlier, the newspaper search reveals a rare reference to seasonal pattern books in May 1858, when David Taylor described his wallpapers as having been "carefully selected from the Pattern Books for 1858,"38 indicating that annual pattern books were circulated internationally, and that the timing of their circulation enabled colonists to participate in the seasonal fashion consumption of northern hemisphere markets.

The 1860s was an important decade as instituting Pākehā culture in New Zealand. The increased availability and use of wallpaper during the decade appears to have been a part of this.

37 "Paperhangings! Paperhangings!! Paperhangings!!! [advert Stallard and Mills]" p 2.

38 "David Taylor, Upholster [advert]" p 4. 


\section{REFERENCES}

"Abstract Of The Receipts and Expenditure Of The Dunedin School Committee" Otago Witness (15 October 1864):3.

"Auckland Provincial Council: Wednesday" Daily Southern Cross (11 May 1865):4.

Brett's Colonists' Guide Thomson W. Leys (ed). Auckland: H. Brett, 1883.

"David Taylor, Upholster [advert]" Otago Witness (15 May 1858):4.

"Dunedin, Wednesday, Dec. 25 ... The house of Mr W.J. Henningham ... " Otago Daily Times (25 December 1967):4.

"Exhibition Paperhangings!! ... [advert Stallard and Mills.]" Nelson Examiner and New Zealand Chronicle (18 March 1863):1.

"Friday, 12th April, 1867.: To Builders, Contractors, Ironmongers ... Mr James Smith." Wellington Independent (9 April 1867):1.

"Furnishing Ironmongery, \&c. [advert F Armson]" The New Zealander (30 August 1849):1.

"Hospital: Tenders for Papering and Painting." Taranaki Herald (23 January 1864):2.

"Inflation Calculator" Reserve Bank of New Zealand http://www.rbnz.govt.nz/statistics/0135595.html

"Junction of Queen and Grey-Streets [advert Edwin S. Brookes]" Daily Southern Cross (20 May 1865):3.

"Just Received, ex Electra [advert W. Tustin]" Evening Post (21 November 1866):3.

"Just Arrived,: Ex "John Bunyan," from London ... At Williams' Oil And Color Store." Hawke's Bay Herald (5 November 1867):2.

Lyna, Dries \& Ilja van Damme "A strategy of seduction?: The role of commercial advertisements in the eighteenth-century retailing business of Antwerp" Business History (January 2009) 51(1):100-121

McCarthy, Christine "Before Official Statistics: the early commerce of wallpaper in New Zealand" Fabrications, forthcoming.
"Marriages" Daily Southern Cross (20 February 1869):3.

"Marriages" Daily Southern Cross (15 February 1870):8.

"Monday, November 7 ... The temporary provision for Supreme Courthouse." Daily Southern Cross (7 November 1864):4.

"Napier Athenæum" Hawke's Bay Herald (22 July 1865):2.

"Notice Of Removal.: David Taylor [advert]" Otago Witness (8 December 1860):4.

"Odd Fellows' Hall,: To Paperhangers, Bricklayers, and Carpenters" Taranaki Herald (5 August 1865):2.

"Paper-Hangers wanted at the New Theatre [advert P. Griffin, at S.W.Alcorn's]" West Coast Times (2 March 1866):3.

"Paperhangings! [advert Stallard and Mills]" Nelson Examiner and New Zealand Chronicle (1 September 1860):2.

"Paperhangings! Paperhangings!! Paperhangings!!! [advert Stallard \& Mills]" Nelson Examiner and New Zealand Chronicle (27 November 1861):2.

"Paper Hangings. - The Cheapest Lot ... W. Jenkins's." Nelson Examiner and New Zealand Chronicle (10 November 1860):4.

"Princess Theatre" Otago Witness (5 August 1865):5.

"Public Works ... Your Committee have accepted ... a sum of L10 5 s." Otago Witness (19 July 1867):8.

"''Sayings of the Ancients"'" Daily Southern Cross (20 December 1872):3.

"Superior Paper-Hangings, Per Electra.: T.B. Louisson" Nelson Examiner and New Zealand Chronicle (25 April 1863):2.

"T.B. Louisson, Painter, Glazier, and House Decorator." Nelson Examiner and New Zealand Chronicle (7 March 1868):2.

"Tenders Accepted." Otago Witness (1 March 1862):5.

"Tenders are invited for the Painting, Papering, \&c., to be done at the Swan Hotel." West Coast Times (17 January 1866):3. 
"Tenders are required [tender Smith and Co.]" Evening Post (31 May 1865):3.

"Tenders are required for Painting [tenders N.W. Dike, Bank of Australasia]" Evening Post (19 June 1866):3.

"Tenders required for the painting and pa-papering[sic] of Manse." Bruce Herald (5 January 1865):9.

"Tenders Wanted for painting [tenders McGuire and Lynch]" West Coast Times (10 November 1866):3.

"Tenders wanted for painting, glazing, calicoing, and papering" Southland Times (18 September 1863):3.

"Tenders Wanted, for Painting and Papering the new building" Daily Southern Cross (15 November 1864):1.

"Tenders wanted, labor only, for Painting, Papering, and Glazing" Southland Times (30 October 1863):5.

"Tenders: Tenders are invited for Paperhanging [advert J.M. Vivian, Foresters Hall]" Taranaki Herald (18 August 1866):2.

"Thursday, December 28: Leasehold Property: Chapel-street" Daily Southern Cross (27 December 1865):2.

"To Painters And Paperhangers [tender A. Whiteford.]" Evening Post (12 July 1865):3.

"To Painters And Paperhangers.: Ben. Smith, Architect." Evening Post (2 October 1867):3.

"To Painters And Paperhangers.: Tenders will be received until Thursday the 6th inst." Wellington Independent (1 April 1865):2.

"To Painters And Paper-Hangers.: Tenders will be received, until noon." Daily Southern Cross (6 December 1865):1.

"To Painters, Paperhangers, Glaziers, Etc. [tender J.B. Cameron]" Daily Southern Cross (28 March 1866):1.

"To Painters.: Tenders will be received ... John Gellatly, Saddler,: Deestreet" Southland Times (22 November 1867):3.
Walsh, Clair "The Advertising and marketing of Consumer Goods in Eighteenth-Century London" Advertising and the European City: historical perspectives ed. Elliott Shore and Clemens Wischermann Aldershot, UK: Ashgate, 2000:79-95.

"Wanted Tenders for Painting and Papering the Union Bank" Southland Times (26 June 1863):3.

"Wanted, Tenders for Canvasing and Papering." Nelson Examiner and New Zealand Chronicle (13 June 1864):4.

"Wanted. Tenders for Painting and Papering Dunedn Hotel." West Coast Times (7 November 1865):3.

Woods, Christine "An object lesson to a philistine age: the Wall Paper Manufacturers' Museum (and the formation of the national collections)" Journal of Design History (1999) 12(2):159-171. 